\title{
Determinants of agricultural land use diversification in eastern and northeastern India
}

\author{
Chandan Kumar ${ }^{a}$ and S. P. Singh ${ }^{b}$ \\ Indian Institute of Technology Roorkee (IITR), India
}

Submitted 17 January 2012 / Revised 31 March, 28 May, and 31 July 2012 / Accepted 5 August 2012 /

Published online 21 October 2012

Citation: Kumar, C., \& Singh, S. P. (2012). Determinants of agricultural land use diversification in eastern and

northeastern India. Journal of Agriculture, Food Systems, and Community Development, 3(1), 73-98.

http://dx.doi.org/10.5304/jafscd.2012.031.004

Copyright (C) 2012 by New Leaf Associates, Inc.

\begin{abstract}
This paper examines factors influencing land use under specific types of crops (e.g., cereals, cash crops including vegetables, horticulture, etc.) as well as the land devoted to livestock activities (dairy, piggery, poultry/duckery, fishery, apiary, etc.) in the eastern and northeastern regions of India comparing the same with the national pattern. We utilize farm-level information collected in the 59th round of the National Sample Survey (January-December 2003). Using multivariate multinomial logistic regression models, we examine the adjusted effect of selected background factors

\footnotetext{
a Corresponding author: Chandan Kumar, Doctoral Candidate (Economics), Department of Humanities \& Social Sciences, Indian Institute of Technology Roorkee (IITR); Roorkee 247 667; Uttarakhand, India; +91-9045795153; c.kumar803@gmail.com

b Professor of Economics, Department of Humanities \& Social Sciences; Indian Institute of Technology Roorkee (IITR); Roorkee- 247 667; Uttarakhand, India; +91-1332-285234; fax: +91-1332-273560; singhfhs@,iitr.ernet.in
}

on the diversified use of agricultural plots at the national level, and for the eastern and northeastern regions separately. The level of diversification was significantly different across level of urbanization, occupational status (as a surrogate variable for household income), educational level of household head, household or family size, farm size, soil type, status of land possession, and waterlogging even after adjusting for religious and social/caste status of the household. The northeastern region reported a higher level of farm diversification compared to the eastern region, while both these regions had lower farm diversification compared to the rest of India. The study results could be used to argue for better and more equitable provision of economic security in terms of credit supply, subsidies, etc., for farmers belonging to Scheduled Castes/Scheduled Tribes in eastern India, and for appropriate land development toward settled cultivation in the northeastern region to augment the agricultural diversification. Some of the prudent steps to boost agricultural diversification in the eastern and northeastern regions of India include enhancing awareness of government- 
sponsored advisory services, and providing economic security to landless farmers and small landholders.

\section{Keywords}

agricultural diversification, agricultural land use, eastern India, multinomial logistic regression, National Sample Survey, India, northeastern India

\section{Introduction}

In India, agriculture is a tradition that has shaped the thoughts, the outlook, the culture, and the economic life of the people for centuries. Agriculture is and will continue to be central to all strategies for planning socioeconomic development of the country (Dhandapani \& Rath, 2004). Although its share in the national GDP is declining, its importance to the economy is best understood in terms of its share of employment and its importance for macroeconomic stability (Government of India [GoI], 2012). Rapid growth of agriculture is essential to achieve not only self-reliance at the national level, but also household food security and equity in distribution of income and wealth, and, consequently, the rapid reduction of poverty levels, development of the rural economy, and enhancement of farm incomes (GoI, 2012; Department of Agriculture \& Cooperation, Ministry of Agriculture [DAC-MOA], 2000a, 2000b).

In terms of poverty and deprivation, the eastern and northeastern regions (Figure 1) of India are in a category of their own. The eastern region comprises Bihar, Jharkhand, West Bengal, Orissa, Chhattisgarh, and the eastern part of Uttar Pradesh (GoI, 2001). The northeastern region includes eight states of the Federal Indian Union, namely Assam, Arunachal Pradesh, Manipur, Meghalaya,
Mizoram, Nagaland, Sikkim, and Tripura (GoI, 2001). As the S. P. Shukla Commission Report (Shukla, 1997) points out in the context of the northeast, the region is confronted by four deficits: a basic need deficit, an infrastructural deficit, a resource deficit, and a two-way deficit of understanding with the rest of the country. The eastern region too faces at least the first three of these deficits. The deficits in eastern and northeastern India have existed for far too long; allowing them to persist any longer would be perilous for the further growth of the region. Enhancing the human development capacity in the region can be achieved only by addressing the key issues of agriculture and allied sectors.

The eastern and northeastern regions have largely been bypassed in the planning process during the last several years. The potential of the east-
Figure 1. Location of Study Area (Eastern and Northeastern Regions of India)

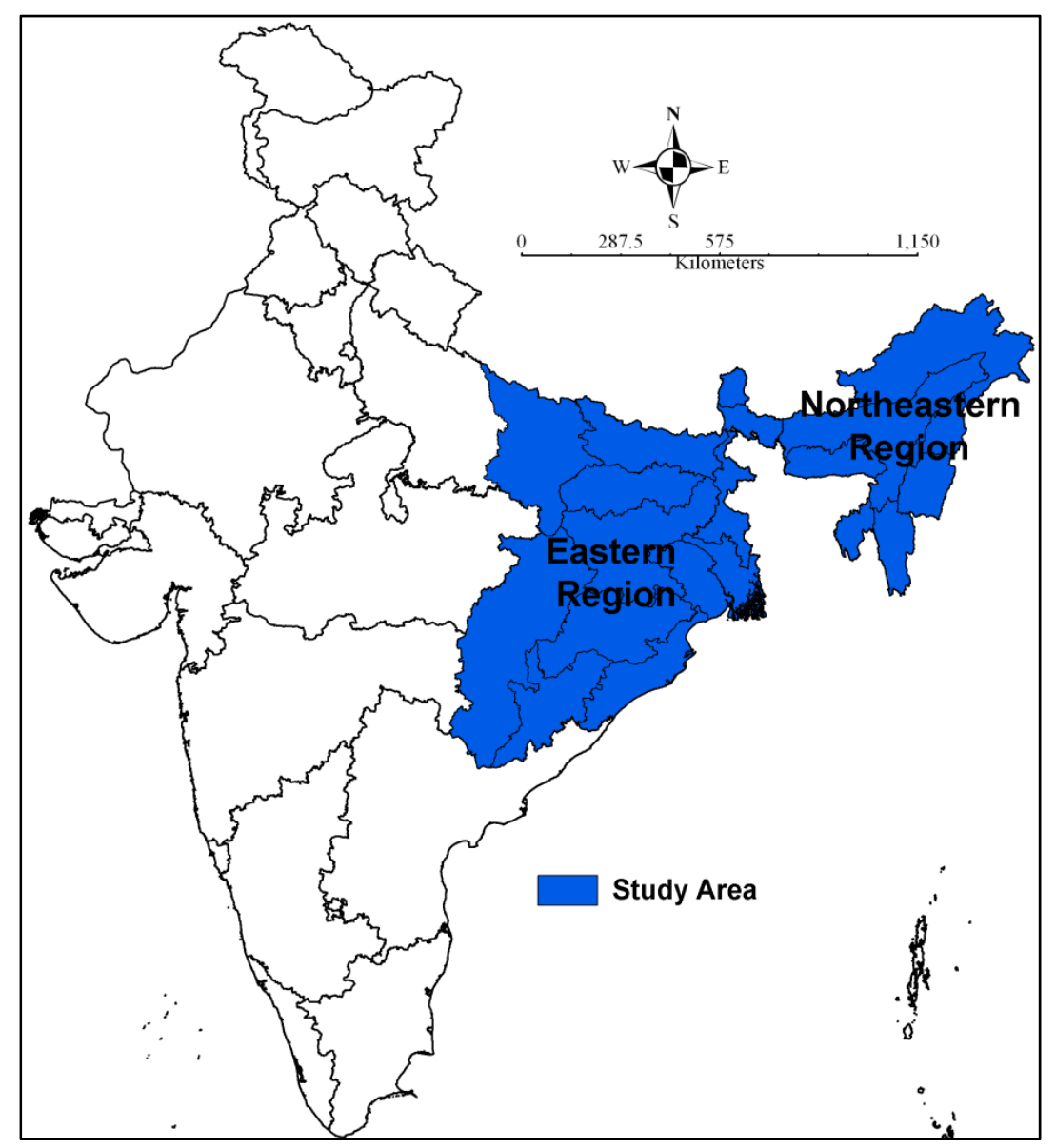


ern and northeastern regions in the spheres of agriculture, horticulture, ${ }^{1}$ animal husbandry, and fisheries is hindered by their low levels of productivity and entrepreneurship (Chatterjee, Saikia, Dutta, Ghosh, Pangging \& Goswami, 2006; GoI, 2001). Due to increasing human population, lack of state land reforms, oral traditions of land ownership, Jbum ${ }^{2}$ cultivation, migrant population, and intensive cultivation, the pressure on land for food and livelihood is on the rise in the northeastern states (Goswami, 2010). States in the eastern region have experienced a marginal decline in the share of cereals' production in the gross cropped area (GCA) from 1970-71 to 2007-08. The levels of crop diversification in Bihar and Jharkhand were much lower than other eastern states (Haque, Bhattacharya, Sinha, Kalra, \& Thomas, 2010). Despite getting low and unstable yield due to erratic southwest monsoons, moisture stress during the crop growth period (although parts of the region also often get flooded), light-textured soils with low water retention and fertility, biological constraints (e.g. weeds, diseases, and pests), farmers in this region grow rice on such land due to their lack of knowledge of alternate sustainable cropping systems (Kar \& Verma, 2002). Crop diversification is identified as a good alternative to deal with persistent challenges and to increase the overall yield in these regions (Haque et al., 2010; Kar, Singh, \& Verma, 2004; National Academy of Agriculture Sciences [NAAS], 2001).

Diversification has been pursued in many countries as a way to improve the long-term viability of agriculture by enhancing the profitability and overall stability of the sector (Guvele, 2001; Van den Berg, Hengsdijk, Wolf, Ittersum, Guanghuo, \& Roetter, 2007; Joshi, P. K., 2004; Kasem \& Thapa, 2011; Papademetriou \& Dent, 2001). Although concerns about food security have led to a policy emphasis on grain self-sufficiency, the potential returns from re-energizing the traditional crop

\footnotetext{
${ }^{1}$ Horticulture in India refers to the gardening and cultivation of fruits, vegetables, flowers, and ornamental plants.

${ }^{2}$ Jhum or Jhoom cultivation is a local name for slash-and-burn agriculture practiced by the tribal groups in parts of the northeastern region of India like Arunachal Pradesh, Meghalaya, Mizoram, and Nagaland.
}

sector alone are now limited, and it would be prudent to identify and promote alternative sources of farm income (GoI, 2008; Gulati \& Ganguli, 2008). Experiences from various countries indicate that a shift in type of production favoring high-value food commodities often creates growth opportunities that can augment income, generate employment opportunities, alleviate poverty, and improve the sustainability of agricultural systems (Chand, 1996; Joshi, P. K., Gulati, \& Cummings, 2007; Pingali, 2004; Rahman, 2009; Ryan \& Spencer, 2001; von Braun, 1995). Relative to cereals, horticulture boosts immense returns to land and generates more farm jobs (Joshi, Gulati, Birthal, \& Tiwari, 2004) as well as off-farm jobs in processing, packaging, and marketing (World Bank, 2007). High-value commodities, particularly horticulture, livestock, and marine products are highly expenditure-elastic when compared with cereals (Kumar, Mruthyunjaya, \& Birthal, 2007). It is also encouraging to note that vegetables, almost without exception, use more organic manure than chemical fertilizers when compared to cereals and other crops. Apart from its income-enhancing ability, vegetable growing thus helps preserve and manage soil fertility, promoting sustainability by protecting soils against degradation through continuous application of higher doses of chemical fertilizers (Bhattacharyya, 2008).

The issue on what influences people's attitude toward the adoption of any new practices or technologies, such as crop diversification, has long been a matter of discussion in literature. Studies from Asia, Africa, and Latin America suggest that no single factor alone leads to change in land use. Several biophysical, socioeconomic, and institutional factors interact and interplay to facilitate the change. Economic status or farmer's risk vulnerability (Anderson, 2003; Benziger, 1996; Dorjee, Broca, \& Pingali, 2003; Pingali, Khwaja, \& Meijer, 2005; Rogers, 1995), educational status and/or knowledge/information of farmer (Aneani, Anchirinah, Owusu-Ansah, \& Asamoah, 2011; Kasem \& Thapa, 2011; Lipton, 1968; Pingali et al., 2005), household size, farm size (Aneani et al., 2011; Kasem \& Thapa, 2011; McNamara \& Weiss, 2005; Singh, Kumar, \& Woodhead, 2002), suitability of soil (Kasem \& Thapa, 2011), structural con- 
straints imposed by institutions and policies on the productive resource base (Binswanger \& McIntire, 1987; Lipton, 1968; Rasul, Thapa, \& Zoebisch, 2004), suitable land-use systems (Danish International Development Agency [DANIDA], 2000; Faminow, Klein, \& Project Operation Unit, 2001; Knudsen \& Khan, 2002;Nagaland Environmental Protection and Economic Development [NEPED] \& International Institute of Rural Reconstruction [IIRR], 1999), and tenurial security (Bugri, 2008; Feder, Onchan, \& Chalamwong, 1988; Thapa, 1998) are among some of the documented factors of agricultural land-use diversification. Studies (Allan, 1986; Reardon, Barret, Kelly, \& Savadogo, 2001; Turkelboom, Van, Ongprasert, Sutigoolabud, \& Pelletier, 1996) have also emphasized the equally important role of infrastructure, including transportation facilities, and access to market centers as they broaden the scope of new crops and technologies facilitating land-use change. However, when information on new technologies becomes available, the socioeconomic characteristics of the target population tend to have a significant effect on their decision to adopt such new technologies (Knowler \& Bradshaw, 2007; Rasul et al., 2004).

With the backdrop of the above inquiries, this paper assesses agricultural land use in India, with special focus on eastern and northeastern regions of the country. The paper examines the impact of the socioeconomic characteristics of farm operators on farm diversification in both regions, which are little understood in the available literature. The paper has no intention of comparing factors influencing agricultural diversification in eastern and northeastern regions, as their agricultural practices and geographical conditions are quite different.

However, socioeconomic indicators influencing the level of diversification in both regions may help illuminate different approaches required to deal with the low level of agricultural diversification in the two underdeveloped regions of India.

\section{Data and Methods}

\section{Data}

National Sample Survey Organization (NSSO) is a pioneer institution in India that provides data based on nationally representative samples on a range of socioeconomic issues. However, comprehensive information on farms, livestock farming, and other allied activities are not recorded very frequently in India. NSSO initially organized a regular assessment of agricultural conditions in the 1950s. After a long gap, it was repeated in 1982 (37th round of the National Sample Survey, or NSS), 1992 (48th round), and 2003 (59th round). In the absence of comprehensive information on agriculture in India for the most recent period, this paper explores the unit-level data of the 59th round of the NSS conducted in 2003. The analysis and implications presented in this paper are not obsolete, as few changes occurred during this short span of time. Appendix A compares selected demographic, socioeconomic, and agricultural indicators of the eastern and northeastern regions of India for 2003 and 2009-10 (that are based on estimates from the Ministry of Agriculture, Government of India and the 66th round of the NSS), and the figures validate our assumption. In addition, Kumar, Kumar, Singh, \& Shivjee (2011) show the trend and patterns of rural employment within the agriculture sector across major states in India in 1983 and 2009-10, which confirms the stable employment levels in the crops sector compared to animal husbandry, forestry, and fishery.

The 59th round of the NSS provides ample information on land and livestock holdings of households as well as the main use of the unit-level operational holdings ${ }^{3}$ during the two agricultural seasons (i.e., Kharif and Rabi). Schedule 18.1 of this round collects information on land and livestock holdings of households. Particulars of the land, irrespective of whether it is owned, leased-in, otherwise possessed, or leased-out, were collected separately for each agricultural plot $^{4}$ operated by

\footnotetext{
${ }^{3}$ An operational holding is a techno-economic unit consisting of all land that is used wholly or partly for agricultural production and is operated (directed and/or managed) by one person alone or with the assistance of others irrespective of title, size, or location. In the context of agricultural operations, a technical unit is understood as unit with more or less independent technical resources, including land, agricultural implements and machinery, draught animals, etc.

${ }^{4}$ The holding may consist of one or more parcels of land or agricultural plots. A household can possess 3 or 4 acres of agricultural area as its operational holding, but this total land
} 
the household. The particulars also include area, form of tenure, agricultural use, irrigation practices, drainage facilities, etc. Data collected in this schedule relate to the calendar year January-December 2003. In order to reduce the recall error, the total information relating to each sample household was collected in two visits. The first visit (January to August) broadly covered the Kharif season, and the second (September to December) included the Rabi season.

A stratified multistage design was adopted for the 59th round survey. The first stage unit (FSU) was the census village (Panchayat wards for Kerala) in the rural sector and UFS (Urban Frame Survey) block in the urban sector. The ultimate stage units (USUs) were households in both sectors. Hamletgroup or sub-block constituted the intermediate stage if these were formed in the selected area. To make the estimates representative and comparable across states/union territories and to account for the multistage sampling design adopted in the survey, we used appropriate weights in the analysis recommended by the NSS. The details of the sampling weights as well as the extensive information on survey design, data collection, and management procedures are described in the 59th round NSS report (NSSO, 2006) and supplementary documents provided with the electronic data disk.

\section{Measures}

The main analysis in this paper has been done using information collected in the fifth block of schedule 18.1 of the 59th round NSS, detailing the main use of each of the agricultural plots operated by households. The unit of analysis is the number of agricultural plots operated by households. The total number of operated agricultural plots was classified into three categories based on their main use. These categories are: cereals (such as paddy, wheat, maize, etc.); cash crops, including pulses, oilseeds, sugarcane, vegetables, orchard products, fiber crops, and fodder; and livestock farming, including dairy, piggery, poultry, duckery, fishery, apiary, and farming of other animals. The diversifi-

holding can be divided among several large and small agricultural plots. cation in land use was defined in terms of higher proportion of plots under the second and third categories.

The total sample of agricultural plots in India analyzed at all levels was 178,310 (168,340 rural, and 9,970 urban). For the eastern region, the sample included 65,694 (63,534 rural and 2,160 urban) agricultural plots, and 18,560 for the northeastern region (16,856 rural and 1,704 urban). The multivariate analysis excluded the sample agricultural plots of Andaman \& Nicobar and Lakshadweep islands in order to assess the level of land use diversification across the main geographical regions of India. These broad geographical regions are formed based on homogeneity and contiguity of states in different parts of the country. The name of the states and their parts included in different geographical regions are listed in Appendix B.

The extent of diversification in the main use of the agricultural plots was assessed using a set of selected background variables directly related to agricultural land and the process of production, as well as with the socioeconomic conditions of the land operators (e.g., cultivators, farmers, etc.). Hence, the agricultural land use classified in three groups (cereals, cash crops, and livestock farming) was considered a dependent variable in the multivariate analysis, the variation of which was predicted by a set of independent variables. The independent variables were the place of residence (rural or urban), religion, social group, level of education of the household head, main occupational status of the household, household size, farm size (area of the agricultural plot), type of soil, kind of land possession, and the waterlogging status of land during the agricultural season.

Most of the independent variables were grouped into categories. Place of residence separates the agricultural and allied activities operated by households in rural and urban areas. The census of India definition of urban/rural is used to classify a household as urban or not (Bhagat, 2005). The religion variable includes three categories: Hindu, Muslim, and "Other." The social group (caste) variable was categorized as Scheduled Castes (SC)/Scheduled Tribes (ST), Other Backward Class $(\mathrm{OBC})$, and "Other." Based on the terminology adopted by the government of India, this classifi- 
cation of social group focuses more on the socially disadvantaged castes/groups, and all privileged caste groups are represented in the "Others" group (Chitnis, 1997). The level of education of the household head was grouped in two categories: illiterate and below primary, and primary and above. Based on the household principal occupation (as per the National Classification of Occupation 1968), the main occupation of the household was classified as Cultivator (including dairy or vegetable grower or farmer in share), Agricultural laborer, Public services (government/local bodies), and Other occupation. The size of the sample household, i.e., the total number of persons normally residing together, was categorized into three groups ( $<5$ members, $5-9$ members, and $\geq 10$ members). Similarly, farm size was divided into three groups based on the area of agricultural plots $(<2.5$ acres $(<1$ hectare), $2.5-3.7$ acres $(1-1.5$ hectare (s)), and $>3.7$ acres $(>1.5$ hectares $))$. An agricultural plot of under one hectare is termed as a marginal land holding in agricultural literature (Chand, Prasanna, \& Singh, 2011; Haque et al., 2010). Soil type indicates texture of the soil; three factors that determine the soil texture are sand, silt, and clay. Depending on their proportions, the soil can be divided into five groups: sand, loam, silt, clay, and clay-loam. However, in the present analysis, this variable is grouped into four categories based on their proportion in the selected area: loam, light clay, heavy clay, and other (including sand, silt, etc.). The type of land tenure is classified into two categories: owned or possessed (irrespective of the lease status, but possessed during the survey); and operated, but not possessed (during the survey). Information on availability of drainage facility was ascertained for agricultural plots by recording their waterlogging status during the agricultural season. If 50 percent or more of the plot was waterlogged, the plot was considered waterlogged.

\section{Statistical Procedure}

The bivariate association between the outcome variable and the independent predictors were assessed using the chi-squared test (Warner, 2008). Since the nature of the outcome or the response variable was nominal and classified into three cate- gories (i.e., polytomous), the analysis used the multinomial logit regression model (Chan, 2005; Kumar et al., 2011; Salasya, Mwangi, Mwabu, \& Diallo, 2007). However, to avoid any complexity in the interpretation and for easier dissemination of results obtained from the regression model, we report the model-based predicted probabilities (PP). These predicted probabilities can be easily converted to percentage form and are well understood. The general formulation of the model in probability form may be specified as follows (Hosmer \& Lemeshow, 1989; Retherford \& Choe, 1993):

$$
P_{j}=\frac{e^{\Sigma_{k} b_{j k} X_{k}}}{1+\Sigma_{i} e^{\Sigma_{k} b_{j k} X_{k}}}, \quad j=1,2, \ldots \ldots, J
$$

where $\mathrm{P}_{j}$ denotes the response variable with $J$ mutually exclusive and exhaustive categories, denoting $j=1,2, . ., J$ (i.e., 3 ). The three probability categories of the response variable are: $\mathrm{P}_{1}=$ estimated probability of using land for cultivation of cereals, $\mathrm{P}_{2}=$ estimated probability of using land for cultivation of cash crops, and $\mathrm{P}_{3}=$ estimated probability of using land for livestock farming. $\mathrm{X}_{0}$ $=1$, the summation $\Sigma_{k}$ ranges from $k=0$ to $k=K$, the summation $\sum_{i}$ ranges from $i=1$ to $i=J-1$, and $b_{j 0}, b_{j 1}, \ldots, b_{j K}$ are all defined to be zero. The latter definition implies that

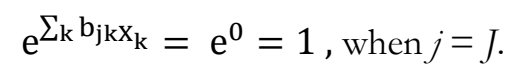

The statistical analysis also accounted for the sampling design used in the NSS by employing survey analysis methods. All analyses were conducted using STATA version 10 (Statacorp, 2007).

\section{Results}

\section{Regional V ariation in Land Use}

More than half the agricultural plots (about 53 percent) were reported as being used for the cultivation of cereals, compared to 21 percent for cash crops and about 26 percent for livestock farming in India (Table 1) in 2003. Eleven out of 28 states and group of union territories listed in Table 1 reported a higher proportion of their total agricultural plots being used for the cultivation of cereals compared to the national average. Seven out of these 11 
states also reported a comparatively lower proportion of agricultural plots under cash crops, and all 11 states had a lower proportion of plots used for livestock farming. The majority of these states (Arunachal Pradesh, Bihar, Chhattisgarh, Jharkhand, Mizoram, Nagaland, Orissa, West
Bengal, and Uttar Pradesh) are part of eastern and northeastern regions of India. Punjab reported the highest proportion (48.9 percent) of agricultural plots for the operation of livestock farming; this was followed by Haryana (48.8 percent), Tamil Nadu (45.9 percent), Karnataka (45.2 percent),

Table 1. Land Use (\%) Under Agriculture and Allied Activities by States/Union Territories, India, 2003

\begin{tabular}{|c|c|c|c|}
\hline \multirow[b]{2}{*}{ State/Union Territory (UT) } & \multicolumn{3}{|c|}{ Agricultural land use (\% and sample size $\mathrm{N}$ (unweighted)) } \\
\hline & Cereals & Cash crops ${ }^{a}$ & Livestock farming \\
\hline Andhra Pradesh & $36.3(2919)$ & $29.9(2282)$ & $33.8(2269)$ \\
\hline Arunachal Pradesh & $70.3(838)$ & $20.1(299)$ & $9.6(145)$ \\
\hline Assam & $48.1(2917)$ & $32.8(1982)$ & $19.1(1038)$ \\
\hline Bihar & $74.6(13640)$ & $10.6(2046)$ & $14.8(2482)$ \\
\hline Chhattisgarh & $66.4(2568)$ & $17.2(640)$ & $16.4(610)$ \\
\hline Goa & $51.0(67)$ & $15.0(28)$ & $34.0(29)$ \\
\hline Gujarat & $33.8(1543)$ & $24.1(1125)$ & $42.1(1376)$ \\
\hline Haryana & 34.3 (1493) & $16.9(747)$ & 48.8 (1581) \\
\hline Himachal Pradesh & 73.6 (5342) & 23.9 (1966) & $2.5(214)$ \\
\hline Jammu \& Kashmir & $51.1(2326)$ & 25.6 (1713) & 23.3 (1019) \\
\hline Jharkhand & $67.2(3204)$ & $16.0(795)$ & $16.8(801)$ \\
\hline Karnataka & 40.0 (2001) & $14.8(887)$ & $45.2(1894)$ \\
\hline Kerala & $21.9(556)$ & $54.6(1047)$ & $23.5(446)$ \\
\hline Madhya Pradesh & 45.5 (4193) & $32.6(3096)$ & $21.9(1722)$ \\
\hline Maharashtra & 43.7 (3770) & 27.6 (2849) & 28.5 (2098) \\
\hline Manipur & 38.5 (1311) & $47.3(1572)$ & $14.2(504)$ \\
\hline Meghalaya & $29.8(613)$ & $50.1(982)$ & $20.0(414)$ \\
\hline Mizoram & $53.8(590)$ & 25.7 (309) & 20.5 (340) \\
\hline Nagaland & $55.7(642)$ & 31.6 (396) & $12.8(143)$ \\
\hline Orissa & $64.8(4367)$ & $16.1(1094)$ & $19.1(1155)$ \\
\hline Punjab & $37.7(1842)$ & $13.5(557)$ & 48.9 (1839) \\
\hline Rajasthan & $45.4(4564)$ & $12.9(1634)$ & $41.8(4052)$ \\
\hline Sikkim & $47.5(768)$ & $27.2(433)$ & 25.3 (393) \\
\hline Tamil Nadu & 32.6 (2028) & 21.5 (1433) & 45.9 (2339) \\
\hline Tripura & 35.4 (716) & $35.0(643)$ & $29.6(572)$ \\
\hline Uttaranchal & $65.1(1688)$ & $19.0(580)$ & 15.9 (381) \\
\hline Uttar Pradesh & $53.6(17570)$ & 21.3 (7839) & $25.1(7914)$ \\
\hline West Bengal & $61.7(10300)$ & 19.7 (3172) & 18.6 (2871) \\
\hline Union Territories incld. Delhi & $32.4(488)$ & $17.2(182)$ & $50.4(477)$ \\
\hline India & $52.9(94864)$ & $21.0(42328)$ & $26.2(41118)$ \\
\hline
\end{tabular}

a Include pulses, oilseeds, sugarcane, vegetables, orchards, fiber crop, and fodder.

b Include dairy, piggery, poultry/duckery, fishery, apiary, and farming of other animals

Note: Proportions are in percent (weighted). Figures in parentheses are sample size 'N' (unweighted). 
Gujarat (42.1 percent), and Rajasthan (41.8 percent). Majority of these states (names mentioned ahead) have a growing economy (Kapoor, 2011).

Figure 2 shows the regional variation in the land use pattern (out of total land area) in the eastern and the northeastern regions of India. Arunachal Pradesh, Bihar, and Eastern Uttar Pradesh reported more than half of the total land devoted to agricultural operations. Bihar and Western West Bengal reported more than two-fifth of their total land under cereals, while Arunachal Pradesh and Mizoram reported considerably higher proportion of land under cash crops. Similarly, Manipur (22.6 percent), Meghalaya (19.5 percent), Tripura (17.5 percent), and Assam (15.1 percent) had relatively larger proportion of land under vegetables and horticulture. Tripura (15.1 percent), Himalayan West Bengal (13.9 percent), and Eastern Uttar Pradesh (13 percent) were the top three regions in terms of land used for livestock farming.

\section{Agricultural Land Use by Selected Background Characteristics}

The eastern region of India recorded 66 percent of agricultural plots under cereals, 16 percent under cash crops, and about 18 percent for livestock farming (Table 2). The corresponding figures for the northeastern region were 46.1 percent, 34.4 percent, and 19.4 percent respectively.

Table 2 presents the proportion (\%) of agricultural plots used under cereals, cash crops and for livestock farming by selected background charac-

Figure 2. Land Use (\%) Pattern Across Regions of Eastern and Northeastern India, 2003

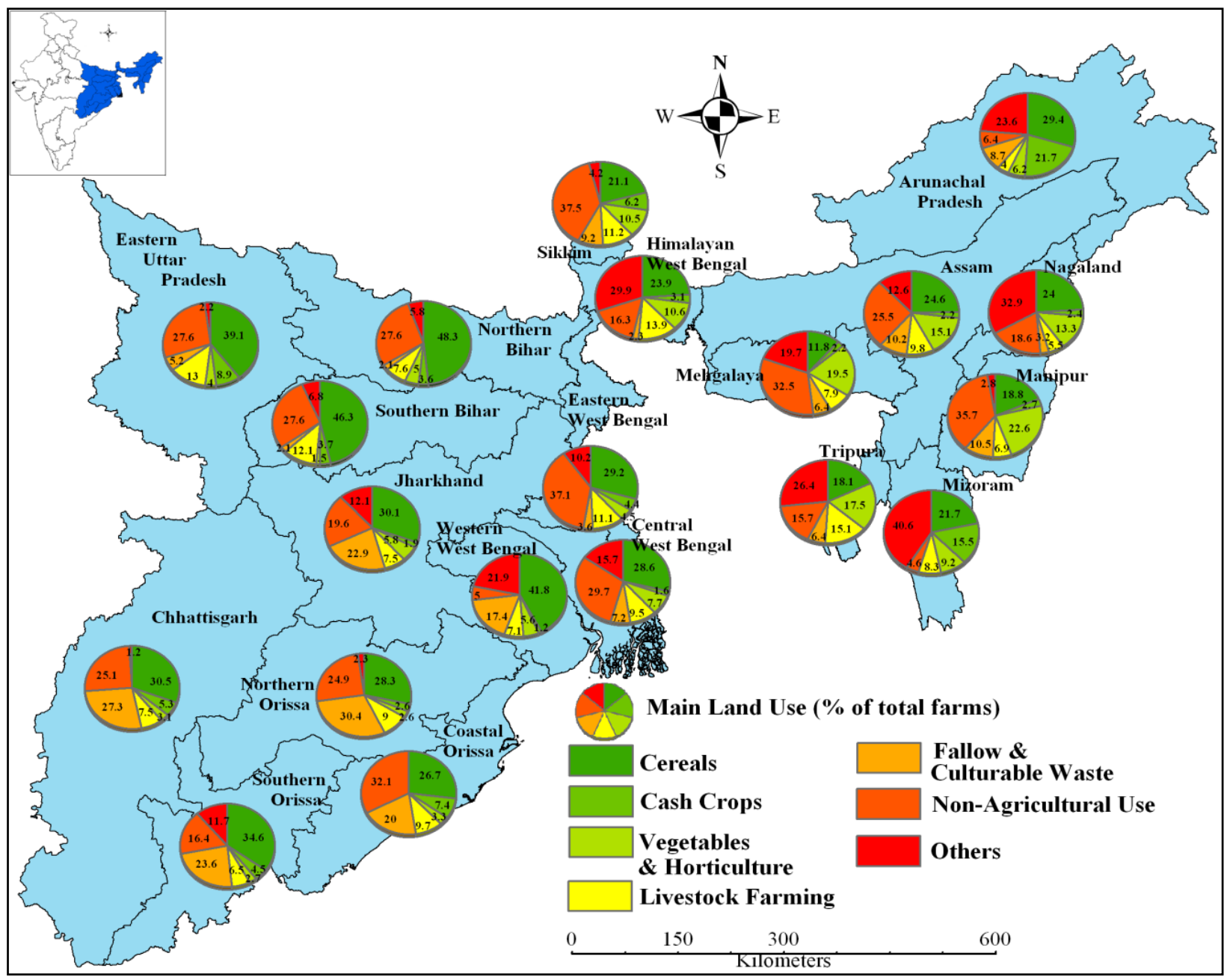

Note: Estimates calculated by authors using 59th Round NSS data. 
teristics of land and its operators. The proportion of agricultural plots used for cultivation of cereals was higher in rural areas compared to urban areas. However, a higher proportion of agricultural plots in urban areas was used for livestock farming compared to rural areas. In the northeastern region, the proportion of agricultural plots under cash crops was higher in urban areas, as compared to the pattern observed in the eastern region and at the national level.

At the national level, households belonging to religions other than Hindu and Islam/Muslim used higher proportion of plots under cash crops (22.3 percent) and for livestock farming (35.7 percent). However, such a distinct pattern is not evident in the eastern and northeastern regions. At the national level, households belonging to "other" social group (non-SC/ST and OBC) used a higher proportion of plots for cash crops (24 percent), while the proportion for livestock farming was higher among SC/ST households (31 percent). The pattern was similar in the eastern and the northeastern regions, except in the northeastern region where the OBC households reported a higher proportion of plots under cash crops. Households with heads educated up to primary level or above reported a higher proportion of plots used for cash crops, while a lower proportion for livestock farming compared to households with their heads not educated up to primary level or illiterate. At the national level, cultivators or farmers had a substantial proportion (23 percent) of land under cash crops, while those who were from "other" occupation, reported a higher proportion (43 percent) of plots used for livestock farming. In contrast, in the northeastern region, households where the main occupation was public services used a higher proportion (41 percent) of plots for cash crops. Moreover, the households with 10 or more members used a higher proportion of plots for cash crops, while households with fewer than five members reported using a higher proportion of plots for livestock farming.

The eastern and northeastern regions of India had a higher proportion of small agricultural plots used for the cultivation of cash crops and livestock farming. At the national level, a higher proportion of agricultural plots having light clay soil were pri- marily used for the cultivation of cash crops, while agricultural plots with "other" soil type were used for livestock farming. However, in the eastern region, a higher proportion of agricultural plots with loam soil was used for cash crops. The proportion of agricultural plots that were owned or possessed by households was higher for the cultivation of cash crops and livestock farming, compared to the plots that were not possessed. Similarly, a lower proportion of agricultural plots that were waterlogged during the season was used for the cultivation of cash crops and livestock farming.

\section{Result of Multivariate Analysis}

Table 3 presents predicted probabilities for agricultural plots used under cereals, cash crops, and for livestock farming, adjusting selected socioeconomic characteristics of operator households as well as the nature of agricultural land. The result of multivariate multinomial logistic regression confirms the urban advantage in cultivation of cash crops and for livestock farming in eastern and northeastern regions of India, although at the national level the probability of using plots for cash crops was relatively higher in rural areas $(\mathrm{PP}=0.202)$ compared to urban areas $(\mathrm{PP}=0.197)$. In eastern regions, Muslim households had a higher probability of using plots for cash crops and livestock farming, while SC/ST households had a lower probability of using agricultural plots for cash crops $(\mathrm{PP}=0.087)$ and for livestock farming $(\mathrm{PP}=0.148)$ compared to households belonging to $\mathrm{OBC}$ and others. In contrast, the probability of using plots under three categories was not statistically different across religious and social groups in the northeastern region. In the eastern region (compared to the northeastern region), the educational level of the head of the household tends to influence the chances of using agricultural plots for cash crops; however, the probability of using plots for livestock farming was lower among households with their heads educated up to primary or above level. The adjusted result also confirms that the households belonging to public-service employees had a higher probability of using agricultural plots for cash crops in the eastern and northeastern regions. In contrast to the national-level pattern, 
Table 2. Proportion (\%) of Agricultural Plots (N) Used for Cereals, Cash Crops, and Livestock Farming, by Selected Background Characteristics, for Eastern and Northeastern Regions and All of India, 2003

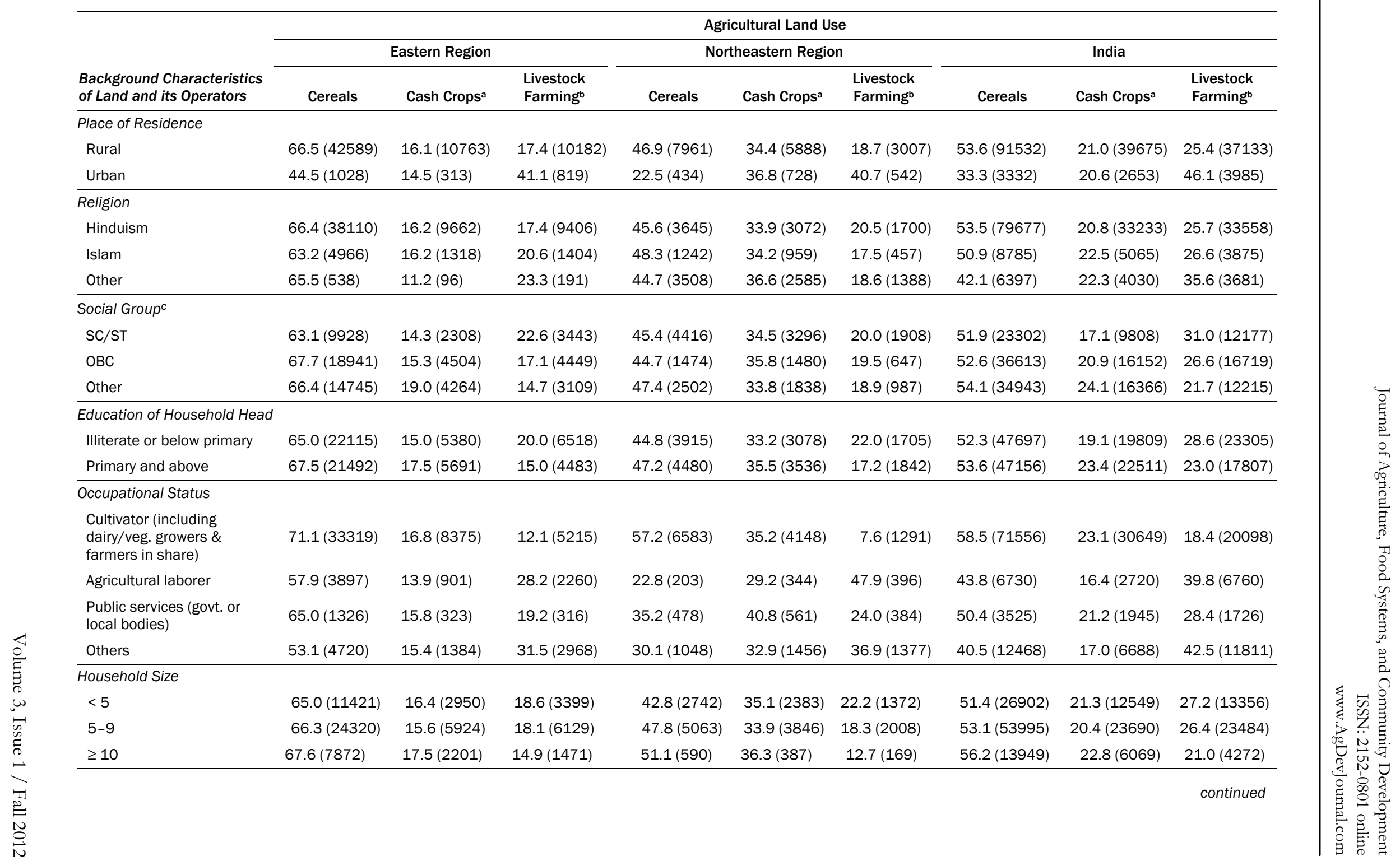




\begin{tabular}{|c|c|c|c|c|c|c|c|c|c|}
\hline \multirow[b]{3}{*}{$\begin{array}{l}\text { Background Characteristics } \\
\text { of Land and its Operators }\end{array}$} & \multicolumn{9}{|c|}{ Agricultural Land Use } \\
\hline & \multicolumn{3}{|c|}{ Eastern Region } & \multicolumn{3}{|c|}{ Northeastern Region } & \multicolumn{3}{|c|}{ India } \\
\hline & Cereals & Cash Crops ${ }^{a}$ & $\begin{array}{l}\text { Livestock } \\
\text { Farmingb }\end{array}$ & Cereals & $\begin{array}{l}\text { Cash } \\
\text { Crops }^{a}\end{array}$ & $\begin{array}{l}\text { Livestock } \\
\text { Farming }\end{array}$ & Cereals & Cash Crops ${ }^{a}$ & $\begin{array}{l}\text { Livestock } \\
\text { Farmingb }\end{array}$ \\
\hline$<1$ ha $(<2.5$ acres $)$ & $65.6(41269)$ & $16.3(10771)$ & $18.1(10754)$ & $43.3(7117)$ & $36.4(6447)$ & $20.3(3397)$ & $52.2(81726)$ & $20.0(36554)$ & 27.9 (39558) \\
\hline $1-1.5$ ha (2.5-3.7 acres) & $87.6(1388)$ & $11.7(180)$ & $0.7(20)$ & $90.6(813)$ & 7.7 (110) & $1.6(29)$ & $67.5(5979)$ & $32.1(2496)$ & $0.4(75)$ \\
\hline \multicolumn{10}{|l|}{ Type of Soil } \\
\hline Loam & $74.7(9727)$ & $11.3(1548)$ & $14.0(1700)$ & $63.2(2321)$ & $23.4(935)$ & $13.4(479)$ & $63.1(18159)$ & $18.2(5722)$ & $18.6(4562)$ \\
\hline Light clay & 79.4 (9759) & $9.8(1242)$ & $10.8(1293)$ & $61.0(2516)$ & $25.6(1211)$ & $13.5(560)$ & $62.6(22715)$ & $21.2(8127)$ & $16.2(5354)$ \\
\hline Heavy clay & $79.7(3387)$ & $7.5(311)$ & $12.8(513)$ & $69.6(246)$ & $9.2(61)$ & $21.2(100)$ & $63.1(5797)$ & 19.9 (1902) & $17.0(1479)$ \\
\hline $\begin{array}{l}\text { Other (including sand \& } \\
\text { silt) }\end{array}$ & $75.9(5242)$ & $10.4(817)$ & $13.7(989)$ & $54.0(754)$ & $23.8(476)$ & $23.8(350)$ & $50.6(12023)$ & 17.9 (4869) & $31.5(6770)$ \\
\hline \multicolumn{10}{|l|}{ Type of Land Tenure } \\
\hline $\begin{array}{l}\text { Operated, but not } \\
\text { possessed }\end{array}$ & $81.2(4341)$ & 14.9 (779) & $3.9(330)$ & $60.5(755)$ & $20.3(305)$ & $19.2(224)$ & $70.4(8123)$ & $21.5(2645)$ & $8.1(1150)$ \\
\hline \multicolumn{10}{|c|}{ Whether Waterlogged During the Season } \\
\hline Yes & $81.2(4707)$ & $10.1(580)$ & $8.7(537)$ & $70.1(1136)$ & $17.6(199)$ & $12.3(159)$ & $73.5(7472)$ & $16.9(1664)$ & $9.6(990)$ \\
\hline No & $64.9(38664)$ & $16.6(10381)$ & $18.6(10300)$ & $44.3(7209)$ & $36.3(6363)$ & $19.3(3145)$ & $51.8(87014)$ & $21.2(40441)$ & $27.0(39606)$ \\
\hline Total $(\mathrm{N})$ & $66.0(43617)$ & $16.1(11076)$ & $17.9(11001)$ & $46.1(8395)$ & 34.4 (6616) & 19.4 (3549) & 52.9 (94864) & $21.0(42328)$ & $26.2(41118)$ \\
\hline
\end{tabular}

a Include pulses, oilseeds, sugarcane, vegetables, orchard fruits, fiber crops, and fodder. $\quad \mathrm{b}$ Include dairy, piggery, poultry/duckery, fishery, apiary, and farming of other animals. c The Indian census social group (caste) variable includes Scheduled Castes (SC)/Scheduled Tribes (ST), Other Backward Class (OBC), and Other.

Note: Proportions are in percent (weighted). Figures in parentheses are sample size $\mathrm{N}$ (unweighted). All bivariate associations are statistically significant (at $p<0.001$ or $p<0.05$ ) based on chi squared test. 
Table 3. Predicted Probabilities for Agricultural Plots Used for Cereals, Cash Crops, and Livestock Farming by Selected Background Characteristics, for Eastern and Northeastern Regions and All of India, 2003

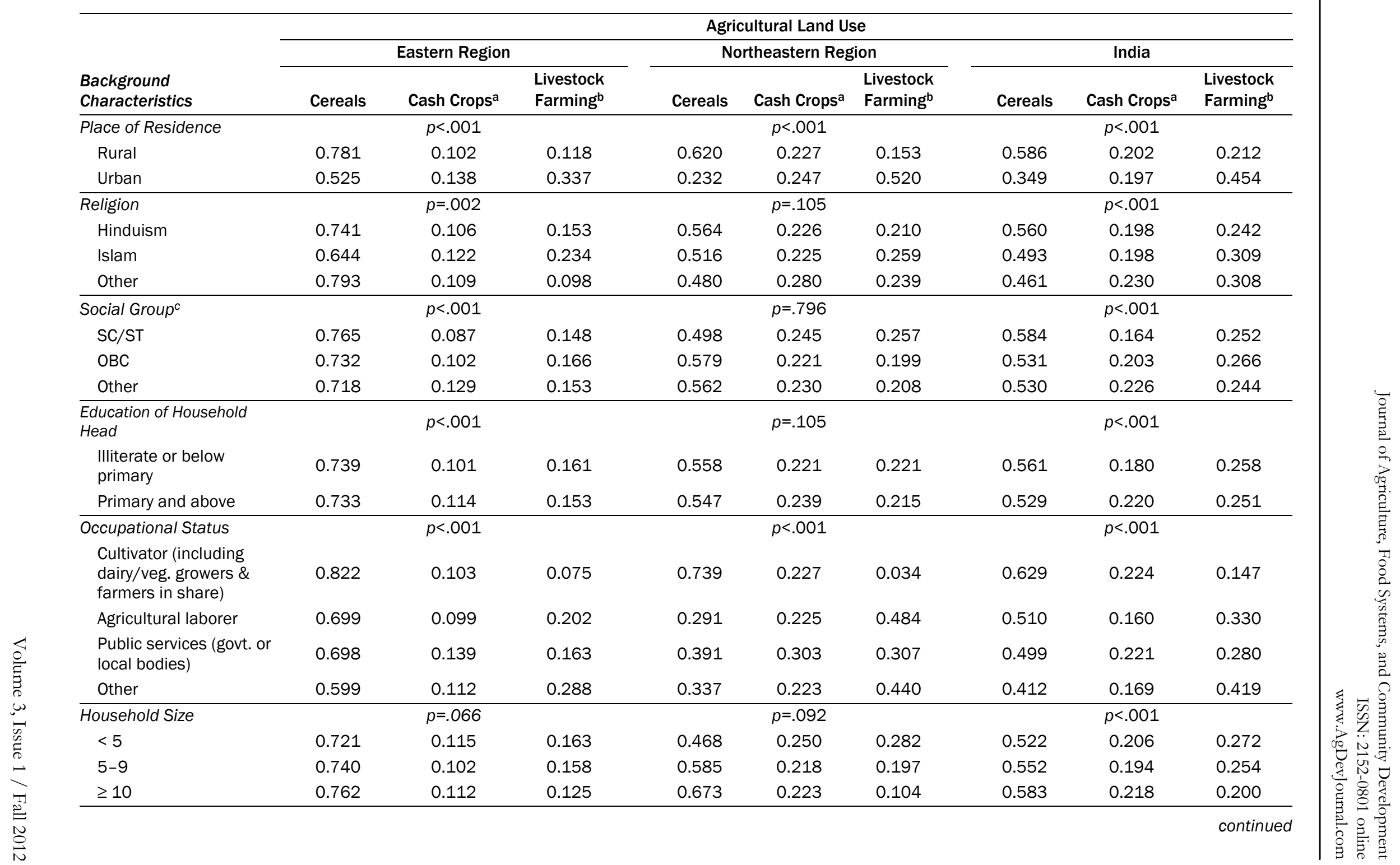




\begin{tabular}{|c|c|c|c|c|c|c|c|c|c|}
\hline \multirow[b]{3}{*}{$\begin{array}{l}\text { Background } \\
\text { Characteristics }\end{array}$} & \multicolumn{9}{|c|}{ Agricultural Land Use } \\
\hline & \multicolumn{3}{|c|}{ Eastern Region } & \multicolumn{3}{|c|}{ Northeastern Region } & \multicolumn{3}{|c|}{ India } \\
\hline & Cereals & Cash Crops ${ }^{a}$ & $\begin{array}{l}\text { Livestock } \\
\text { Farming }\end{array}$ & Cereals & Cash Crops ${ }^{a}$ & $\begin{array}{l}\text { Livestock } \\
\text { Farming }\end{array}$ & Cereals & Cash Crops $^{a}$ & $\begin{array}{l}\text { Livestock } \\
\text { Farming }\end{array}$ \\
\hline Farm Size (in hectare (acre)) & \multicolumn{3}{|c|}{$p<.001$} & \multicolumn{3}{|c|}{$p<.001$} & \multicolumn{3}{|c|}{$p<.001$} \\
\hline$<1$ ha $(<2.5$ acres $)$ & 0.717 & 0.113 & 0.170 & 0.516 & 0.249 & 0.235 & 0.536 & 0.188 & 0.277 \\
\hline $1-1.5$ ha (2.5-3.7 acres) & 0.937 & 0.060 & 0.003 & 0.961 & 0.024 & 0.015 & 0.669 & 0.328 & 0.002 \\
\hline$>1.5$ ha (> 3.7 acres $)$ & 0.953 & 0.040 & 0.007 & 0.976 & 0.011 & 0.012 & 0.624 & 0.373 & 0.002 \\
\hline Type of soil & \multicolumn{3}{|c|}{$p<.001$} & \multicolumn{3}{|c|}{$p<.001$} & \multicolumn{3}{|c|}{$p<.001$} \\
\hline Loam & 0.723 & 0.118 & 0.159 & 0.583 & 0.247 & 0.169 & 0.596 & 0.189 & 0.215 \\
\hline Light clay & 0.771 & 0.103 & 0.126 & 0.570 & 0.253 & 0.177 & 0.593 & 0.224 & 0.183 \\
\hline Heavy clay & 0.764 & 0.080 & 0.156 & 0.692 & 0.086 & 0.222 & 0.586 & 0.205 & 0.209 \\
\hline $\begin{array}{l}\text { Other (including sand \& } \\
\text { silt) }\end{array}$ & 0.699 & 0.113 & 0.188 & 0.466 & 0.232 & 0.303 & 0.435 & 0.184 & 0.380 \\
\hline Type of Land Tenure & \multicolumn{3}{|c|}{$p<.001$} & \multicolumn{3}{|c|}{$p<.001$} & \multicolumn{3}{|c|}{$p<.001$} \\
\hline Owned or possessed & 0.729 & 0.107 & 0.164 & 0.558 & 0.243 & 0.199 & 0.538 & 0.199 & 0.263 \\
\hline $\begin{array}{l}\text { Whether Waterlogged During } \\
\text { the Season }\end{array}$ & \multicolumn{3}{|c|}{$p<.001$} & \multicolumn{3}{|c|}{$p<.001$} & \multicolumn{3}{|c|}{$p<.001$} \\
\hline Yes & 0.861 & 0.065 & 0.074 & 0.750 & 0.106 & 0.144 & 0.754 & 0.161 & 0.085 \\
\hline No & 0.728 & 0.110 & 0.161 & 0.540 & 0.238 & 0.222 & 0.532 & 0.203 & 0.265 \\
\hline Regions of India & & & & & & & \multicolumn{3}{|c|}{$p<.001$} \\
\hline Northern & & & & & & & 0.497 & 0.161 & 0.342 \\
\hline Western & & & & & & & 0.400 & 0.290 & 0.310 \\
\hline Southern & & & & & & & 0.395 & 0.245 & 0.360 \\
\hline Central & & & & & & & 0.404 & 0.321 & 0.275 \\
\hline Eastern & & & & & & & 0.755 & 0.104 & 0.141 \\
\hline Northeast & & & & & & & 0.581 & 0.240 & 0.179 \\
\hline
\end{tabular}

a Includes pulses, oilseeds, sugarcane, vegetables, orchard fruits, fiber crops, and fodder. $\quad$ b Includes dairy, piggery, poultry/duckery, fishery, apiary, and farming of other animals. c The Indian census social group (caste) variable includes Scheduled Castes (SC)/Scheduled Tribes (ST), Other Backward Class (OBC), and Other.

$p$ value denotes the level of significance obtained from the adjusted Wald test. 
small households ( $<5$ members) had a higher probability of using plots for cash crops in the eastern and northeastern regions. The probability of opting for livestock farming was higher among small households across all of India.

The marginal farms $(<2.5$ acres or $<1 \mathrm{ha})$ recorded the highest probability of being used for the cultivation of cash crops and livestock farming. In the eastern and northeastern regions, the agricultural farms with loam soil had a higher probability of being used for the cultivation of cash crops even after controlling for other factors, ${ }^{5}$ while it was plots with light clay soil at the national level. In contrast to the bivariate result, nonpossessed agricultural plots had a higher probability of being used for the cultivation of cash crops, although this was not the case in the northeastern region. However, the probability of livestock farming was higher for nonpossessed agricultural plots in the northeastern region. The plots that were not waterlogged during the season had a higher probability for the cultivation of cash crops and livestock farming.

The result also confirms that the eastern region had the lowest probability for using the agricultural plots for cash crops and livestock farming compared to other regions in the country. The northeastern region also registered a comparatively lower probability for land use diversification. However, the probability of using plots for cash crops in the northeastern region was relatively higher compared to the eastern and the northern region, if compared across all regions in the country, while for livestock farming it was only higher than the eastern region.

\section{Discussion}

The result of the multivariate multinomial logistic

\footnotetext{
${ }^{5}$ The loam soil is characterized as moist, loose and full of biomaterial such as decaying worms and microbes that can be recycled as food for plant life. Because of this, loam soil is considered as the best soil to grow vegetables, garden fruits and flowers such as roses. The soil gets its nutritious qualities from decaying insects and other animals and plants. The $\mathrm{pH}$ level of loam ranges as different ingredients are present in different proportions due to variations in the soil composition, but the standard loam pH is between 5 and 7 , which is optimum range to grow a variety of vegetables and fruits (Walworth, 2009).
}

regression model brings to light certain relationships between households' socioeconomic characteristics and the nature of agricultural land, and the diversification of land use toward high-value commodities (HVCs) and allied activities. Results show that urbanization has a positive and significant influence on the diversification of agricultural plots. It seems to be an obvious outcome, as the capital investment capacity of the household and the use of new technology and knowledge are more prominent in urban areas. Rao, Birthal, Joshi, \& Kar (2004) have found that a majority of the districts in urban India were in the high and medium diversification zones. The cost advantage in transportation of HVCs and their quick sale are the principal reasons that farmers close to urban centers are more competitive than far-off farmers. With the development of roads and other infrastructure facilities, districts surrounding urban centers tend to supply HVCs to urban districts. The demand for HVCs is rising in urban districts much faster than other areas due to rising percapita income and changes in tastes and preferences. To meet the demand for HVCs in urban areas, agriculture is transforming from food grainbased to high-value agriculture. The structural shifts (urbanization) have a positive impact on demand for vegetables, fruits, meat, fish, and eggs as well (Kumar \& Mathur, 1996).

Several studies have shown that the urbanization, infrastructure development (especially markets and roads), price policy, and technological improvements strongly influence the level of agricultural diversification (Barghouti, Kane, Sorby, \& Ali, 2004; Chand et al., 2011; De \& Chattopadhyay, 2010; Joshi et al., 2004; Rao et al., 2004, 2006; Singh \& Sahoo, 2007). The level of urbanization here does not mean merely the shifting of population toward the non-agricultural activities; it also indicates the optimum infrastructure development to combat the modern globalized agriculture sector. In India's eastern and northeastern states, agriculture is struggling to achieve even a satisfactory status of infrastructure development in comparison to the other states in the country. The main constraints to agricultural diversification in these regions appear to be an inadequate supply and/or erratic availability of electricity, hindering the use 
of modern agricultural equipment such as cold storage and food processing industries; poor condition of roads; inadequate linkages to the market; lack of marketing facilities, including storage and processing of farm outputs; lack of or poor quality agriculture extension facilities; poor diagnostic laboratories for both crops and livestock; and the unprofessional attitude of authorities. The loss of horticultural produce due to the lack of postharvest and food-processing facilities in Bihar and Uttar Pradesh were well documented in a study conducted by the Association for Social and Economic Transformation (ASET) and administered by the Planning Commission (GoI, 2004).

We also examined whether the religious and caste affiliation of a household had any influence in determining the use of agricultural plots for highvalue crops and livestock farming. Muslim households were relatively advantageous in diversifying their land use compared to Hindu households in India, including the eastern region, due to the fact that a majority of the Muslim population in India is concentrated in urban areas (Joshi et. al., 2003; Prasad, 2004). Although, as we estimated from NSS data, some border states like West Bengal, Assam, Meghalaya, and Tripura had relatively low proportions of Muslim population living in urban areas, they are nevertheless closer to urban surroundings. Studies of the border belt of West Bengal found that 20 to 40 percent of villages in the border districts were said to be predominantly Muslim, including Bangladesh immigrants. Several towns in the border districts are surrounded by villages that are mostly dominated by the minority community. A similar situation has been observed in the border districts of northeastern states (Singh, 2009). Moreover, a relatively higher proportion of the Muslim population in these regions has marginal holdings, which may also trigger them to diversify their agricultural and allied activities. On the other hand, the religious and social (caste) groups did not have statistically significant influence in the northeastern region, in contrast to the eastern region and India as a whole.

In the eastern region, the farms belonging to "other" social group (non-SC/ST and OBC) were more likely to be used for high-value crops compared to SC/ST and OBC groups, while they had a lower probability of being used for livestock farming. This may have an economic as well as a sociopsychological explanation that hinders the diversification of land use across different social groups. An economic explanation can be presented while arguing why households in the SC/ST and OBC groups were slow to diversify their land toward high-value crops. Studies argue their deprivation in terms of inadequate capital, knowledge, skill, social ascription, and sponsorship. However, the government has initiated and implemented several plans related to credit provision through loans, agricultural debt waiver and debt relief, agricultural insurance (e.g., the National Agricultural Insurance Scheme, 1999-2000 and 2010), and others, in order to ease the capital impediments in the agriculture sector. Under the Kisan Credit Card (KCC) plan introduced in 1998-99, there were almost 100.93 million credit cards issued in the country as at the end of March 2011 (National Bank for Agriculture and Rural Development [NABARD], 2011). Uttar Pradesh accounted for nearly 18 percent of the total cards issued, followed by Andhra Pradesh (16.9 percent), Maharashtra (9 percent), Tamil Nadu (6.5 percent), Karnataka and Madhya Pradesh (6 percent each). These statistics also reveal the unsatisfactory participation of eastern and northeastern states in order to utilize mainstream national initiatives.

On the other hand, the lower probability to operate livestock farming among the "other" social group may have a sociopsychological basis. In the eastern region, the non-SC/ST and OBC group hesitates to take up animal husbandry as a job, reflecting an age-old traditional mindset irrespective of the level of education. The data suggest that household heads with education up to primary or above were less likely to operate livestock farming. The majority in the "other" social group in the eastern region perceives animal husbandry as a low-skilled job and not of good social repute. However, the fact that 15 percent of agricultural plots belonging to "other" social groups and educated household heads was likely to be used for livestock farming in the eastern region suggests other possibilities. The alternate prospect suggests that the "other" social group and educated people in the eastern region might opt for livestock farm- 
ing at a large-scale professional level instead of low-scale household level. However, such a trend needs to be an avenue of further research and exploration.

A positive relationship between economic status (or income) and level of agricultural diversification is well indicated in the literature (Anderson, 2003; Ellis, 1989; Rogers, 1995). The surplus money enables the households to acquire assets and equipment necessary to cultivate highvalue crops and other such allied activities. In the absence of an income indicator, this paper used the main occupational status of the household as a proxy of household economic standard and hypothesized that if households had a permanent income source (having a public services employee in the household), they would be likely to grow high-value crops. The result confirms the hypothesis in the case of the eastern and northeastern regions. However, this does not stand true in the case of livestock farming; as discussed above, the operation of animal husbandry has encumbrances beyond economic solution.

The result shows that with an increase in household size, the probability of using agricultural plots for HVCs and for livestock farming decreases in the eastern and northeastern regions. This suggests that the traditional cereal-based agriculture in these regions is not able to subsume or benefit excess involving labors and it results in the loss of farmers from the agricultural sector to the life of unhealthy city slums. Several studies on rural employment diversification in India (Basant \& Kumar, 1989; Chadha \& Sahu, 2002; Kumar, 2009; Mukhopadhyay \& Rajaraman, 2007; Visaria, 1995) have concluded that the share of rural nonfarm employment has grown significantly over time, and the capacity of the farm sector to absorb additional labor has almost reached a plateau.

Studies show that the small size of holdings positively affects agricultural diversification (Aneani et al., 2011; Chand et al., 2011; Kasem \& Thapa, 2011; Kumar et al., 2011; Pingali, 2006; Singh \& Sahoo, 2007). The households having small-sized agricultural plots or holdings tend to exploit as many returns as they can. The cultivation of traditional crops would not prove profitable for them, so they embark on the cultivation of HVCs or livestock farming in order to generate more household income. However, the development of infrastructure and market-friendly environment also affects the agricultural diversification in marginal holdings (De \& Chhattopadhyay, 2010). Thus, a relatively higher proportion of small-size agricultural plots in urban areas were observed growing HVCs compared to rural areas. Kasem \& Thapa (2011) argue in the case of Thailand, "Considering the significantly smaller landholdings of the diversified farmers, they have considerably more household labor available for crop cultivation" (p. 623). This enables the farmers with a relatively large labor force to adopt crop diversification. Empirical evidence on commercialization trends in smallholder agriculture are provided by Dyck, Huang, and Wailes (1993) for East Asia; Huang \& Rozelle (1994) for China; Koppel \& Zurick (1988) and Naylor (1991) for Southeast Asia; and Rasul \& Thapa (2003) for Bangladesh.

The study also appraises that the agricultural plots that were not possessed or taken on lease by the households for agricultural operation during the season, were more likely to be used for HVCs. The pattern supports the hypothesis of maximum remunerative returns from the agricultural land taken on lease. Our estimate from the NSS data suggests that more than 55 percent of agricultural plots that were not possessed but were operated by households, were taken on lease against a fixed price, 8 percent against a fixed produce, and about 19 percent against share of produce in India in 2003. However, the pattern of using such agricultural plots varies in the eastern and northeastern regions. While the returns from nonpossessed plots were obtained using HVCs in the eastern region, households in the northeastern region appeared to operate livestock farming on such nonpossessed plots for high remunerative returns.

\section{Policy Implications}

The significant impact of social structure on farm diversification, especially in the eastern region, indirectly reflects that there is gap in providing policy benefits equitably to all strata of Indian society. Credit supply to the agriculture sector has greatly increased, with an estimated growth rate of 14.3 percent per year between 1996-97 and 2003- 
04. However, further investigation on who are the beneficiaries and which region they belong would be of value. Are the farmers of lower strata aware of or do they have access to these facilities? The data suggest that farmers belonging to SC/ST group in Bihar operated almost 12 percent of nonpossessed (or taken on lease) agricultural plots in 2003. The corresponding figures for farmers belonging to $\mathrm{OBC}$ and the "other" social group were recorded as 8 percent and 6 percent respectively. West Bengal (10 percent) and Orissa (9.5 percent) had also a considerable proportion of such agricultural plots operated by farmers in the SC/ST group. This suggests that landless farming is attached to greater risk, especially in lack of adequate infrastructure and other facilities. Farmers belonging to SC/ST group tend to cultivate nonpossessed or leased-in land, proportionally more than the other social groups. Therefore, they avoid taking risks in cultivation of nontraditional crops, mostly the early perishable crops, in order to be assured of no loss in output. In such situations, farmers of the eastern region, mainly in Bihar, West Bengal, and Orissa, need to be provided special support and consideration by the government. The credit deposit ratio of commercial banks in Bihar is lower than that of most other states in the country.

In order to make credit a powerful aid for agricultural development, the steering group report (Government of Bihar [GoB], 2010) advocates for several efforts: fulfilling the inclusive banking targets given by the Reserve Bank of India in all districts of Bihar by the next five years; at least half the cultivators should be members of reformed cooperatives or bank-linked Self-Help Groups (SHGs); and other credit disposal measures. The steering group report has also proposed a "credit plus" approach to be adopted by the Regional Rural Banks in order to accomplish the above objectives, which involve (a) a holistic view of the credit requirements of poor households; (b) formation of SHGs and their linkages with banks; (c) establishment of rapport with the civil society institutions in the area; (d) decentralization and greater autonomy for the regional offices and local branches; (e) review of the personnel policy in the light of the commitment to "inclusive banking"; and (f) ensuring commitment, involvement and accountability at the top level. All the state governments in the eastern region need to follow these suggestions. The Planning Commission (GoI, 2001) report also asserts that micro-credit, promotion of SHGs, and provision of sharing capital assistance should be stepped up in these regions. Haque and colleagues (2010) also identify lack of timely irrigation, nonavailability of credit, nonavailability of land, lack of information and knowledge, and lack of institutional support as some of the constraints greatly influencing the low level of crop diversification in the eastern region.

In the northeastern states, having a substantial proportion of agricultural land remain fallow during the season certainly affects the agricultural production. In addition, productivity of crops under Jhum is very low because of rain-fed conditions, lack of proper inputs, and production technologies. Based on observations in Mizoram, India, Lianzela (1997) claimed that if the Jbum cycle were below 10 to 12 years, it would no longer be an economic form of agriculture compared to possible types of settled agriculture. The frequent return of farmers to the same land not only results in a decline in yield, but also reduces biomass production per unit area. To have a productive shifting cultivation, the length of the fallow period should not be less than 10 years, but this is practically impossible under the existing socioeconomic conditions, where the landto-person ratio is too low (Lianzela, 1997). In order to facilitate settled cultivation in these areas, attention should be given to appropriate land development. However, innovations developed by integrating the merits of traditional and modern farming systems could offer more effective means of addressing the problems of mountain (slashand-burn) farming system (Tangjang, 2009).

Level of education is positively associated with agricultural diversification. Educated farmers can quickly transfer knowledge and innovation to the field, as required for the integrated intensive farming system. The lower level of literacy and education in the eastern and northeastern regions hinders the extension of agricultural diversification. The Government of India is now providing mass media support to farmers through Doordarshan infrastructure and All India Radio (AIR) broad- 
casting of agriculture-related information. Kisan (Farmer) Call Centers (KCC) provide agricultural information to the farming community through toll-free telephone lines. In addition, agri-clinic and agri-business centers by agriculture graduates provide extension services to farmers on a fee basis by setting up economically viable self-employment ventures, and disseminating information through agri-fairs. However, the impact evaluation of KCC by Administrative Staff College of India [ASCI] (2006) shows that the average value of benefit realized by farmers through counseling varied from state to state. The five states with the highest number of callers were Rajasthan, Uttar Pradesh, Madhya Pradesh, Gujarat, and Tamil Nadu (Pastakia \& Oza, 2011). The extension and awareness of these services need to be more broadly disseminated to the majority of farmers in the eastern and northeastern regions. There is also a need to explore and address the lack of agricultural consulting services sought by the people in these regions. Complacency and a skeptical attitude about the stringent procedures required for government programs, as well as the lack of other required infrastructure and credit, might be some of the factors responsible for people not striving for better alternatives. After a day of work in the field or hunting for their livelihood, people tend to rest or switch to entertaining programs on the radio or television rather than government-sponsored programs on agricultural issues.

An evaluation study on Rural Infrastructure Development Fund (RIDF) projects carried out in Chhattisgarh and Uttar Pradesh showed that the infrastructure index (e.g., irrigation, connectivity, social sectors) as an independent variable explained 54-78 percent of variation in agricultural productivity in the two states (NABARD, 2010). However, the states in the eastern and northeastern regions could only utilize 72 percent and 66 percent under RIDF (I to XVI), compared to other regions where more than 80 percent fund under RIDF were utilized as of 31 March, 2011 (NABARD, 2011). Thus, rural investment-on roads, transport, water impoundment, market, information, and communication infrastructuresis desperately needed in the eastern and northeast- ern regions in order to augment the growth of the rural farm and nonfarm sectors.

\section{Conclusion}

Based on farm-level information, this study assessed the proportionate use of agricultural farms or plots in order to determine the level of farm diversification toward high-value crops and livestock farming across states in India. Identifying a low level of farm diversification across states in the eastern and northeastern regions of India, the study manifested the land-use pattern across geographical regions in both of the low-diversified areas. The use of agricultural plots by selected background characteristics of the land and agricultural operators was described at length. Finally, using multivariate multinomial logistic regression models, the paper examined the adjusted effect of selected background characteristics on the diversified use of agricultural plots at the national level, and for the eastern and northeastern regions separately. Although the differential impact of selected variables on land-use diversification was assessed in different regions, the level of diversification was significantly different with the level of urbanization, occupational status (as a surrogate variable for household income), educational level of household head, household/family size, farm size, soil type, and status of land possession and waterlogging, even adjusting for religious and social/caste status of the household. After adjusting a number of household and land characteristics, the level of farm diversification was assessed lower in the northeastern region and the lowest of all in the eastern region, compared to other regions of India. We also acknowledge a few limitations of this study; the analysis did not take into account several important factors due to unavailability of information at farm level, including the role of infrastructure in terms of road length or market access, irrigation facilities, use of fertilizer, and other farm equipment like tractors. Moreover, the outcome variable included livestock farming as a category, which also prevented the use of a few agriculturerelated variables such as irrigation facilities, for which data was available. 
Journal of Agriculture, Food Systems, and Community Development ISSN: 2152-0801 online

www.AgDevJournal.com

\section{Acknowledgements}

The authors express their gratitude to four anonymous referees for useful comments

facilitating improvements in the paper. We also acknowledge the support provided by IIPS, Mumbai, for accessing required computational software. 


\section{Appendix A}

\section{Demographic, Socioeconomic, and Agricultural Indicators of India's Eastern and Northeastern States, 2003 and 2009-10}

\begin{tabular}{|c|c|c|c|c|}
\hline \multirow[b]{2}{*}{ Variables } & \multicolumn{2}{|c|}{2003} & \multicolumn{2}{|c|}{$2009-10$} \\
\hline & Eastern Region & Northeastern Region & Eastern Region & Northeastern Region \\
\hline & \multicolumn{4}{|c|}{ Demographic and Socioeconomic Indicators (\%)a } \\
\hline \multicolumn{5}{|l|}{ Area of Residence } \\
\hline Rural & 83.1 & 86.1 & 82.7 & 84.4 \\
\hline Urban & 16.9 & 13.9 & 17.3 & 15.6 \\
\hline \multicolumn{5}{|l|}{ Religion } \\
\hline Hinduism & 85.1 & 62.0 & 83.7 & 61.3 \\
\hline Islam & 13.0 & 21.5 & 14.7 & 22.3 \\
\hline Other & 1.9 & 16.5 & 1.6 & 16.5 \\
\hline \multicolumn{5}{|l|}{ Social Group ${ }^{b}$} \\
\hline SC/ST & 33.5 & 31.7 & 33.3 & 38.3 \\
\hline $\mathrm{OBC}$ & 36.1 & 22.1 & 36.5 & 25.4 \\
\hline Other & 30.4 & 46.2 & 30.2 & 36.3 \\
\hline \multicolumn{5}{|l|}{ Household Size } \\
\hline$<5$ & 43.7 & 44.8 & 53.1 & 47.9 \\
\hline $5-9$ & 50.0 & 52.0 & 43.7 & 50.8 \\
\hline$\geq 10$ & 6.4 & 3.2 & 3.2 & 1.4 \\
\hline \multicolumn{5}{|l|}{ Rural Household Type } \\
\hline $\begin{array}{l}\text { Self-employed in nonagriculture } \\
\text { position }\end{array}$ & 16.2 & 15.8 & 19.0 & 19.3 \\
\hline Agricultural laborer & 28.3 & 15.0 & 27.2 & 12.3 \\
\hline Other labor & 6.7 & 11.6 & 12.8 & 10.4 \\
\hline Self-employed in agriculture & 40.0 & 43.7 & 30.1 & 44.4 \\
\hline \multirow[t]{2}{*}{ Other } & 8.8 & 13.9 & 11.0 & 13.6 \\
\hline & \multicolumn{4}{|c|}{ Agricultural Indicators ('000 ha ('000 acre)) } \\
\hline \multicolumn{5}{|l|}{ Area under crops } \\
\hline Kharif cereals & $3,252.5(8,037.1)$ & $222.7(550.3)$ & $2,668.3(6,593.5)$ & $243.7(602.2)$ \\
\hline Rabi cereals & $17,819.9(44,033.9)$ & $624.2(1,542.4)$ & $18,163.0(44,881.8)$ & $679.0(1,677.8)$ \\
\hline Fruits \& vegetables ${ }^{d}$ & $3,917.0(9,679.1)$ & $505.0(1,247.9)$ & $4,142.0(10,235.1)$ & $476.0(1,176.2)$ \\
\hline Food grains & $46,408.6(114,678.1)$ & -) $3,746.8(9,258.5)$ & $44,086.6(108,940.4)$ & ) $3,646.2(9,010.0)$ \\
\hline
\end{tabular}

Note: Demographic and socioeconomic indicators for year 2003 and 2009-10 are estimated from the 59th Round (Sch. 18.1: Land and Livestock Holdings) and 66 $6^{\text {th }}$ Round (Sch. 10: Employment and Unemployment) National Sample Survey (NSS) data, respectively. Agricultural indicators represent the year 2003-04 and 2009-10, which were collected by the Ministry of Agriculture, Government of India. Kharif season is observed January-August and Rabi season September-December.

a Figures are based on household-level data.

b The Indian census social group (caste) variable includes Scheduled Castes (SC)/Scheduled Tribes (ST), Other Backward Class (OBC), and Other.

c Figures are based on state-level estimates provided by Ministry of Agriculture, Government of India.

d Area under fruits and vegetables are for 2002-03 and 2006-07. 
Appendix B

\section{Major Geographical Regions of India}

\section{Regions States or Part of States Included}

Northern Chandigarh, Delhi, Haryana, Himachal Pradesh, Jammu \& Kashmir, Punjab, Rajasthan,

Uttarakhand

Western Dadra \& Nagar Haveli, Daman \& Diu, Goa, Gujarat, Maharashtra

Southern Andhra Pradesh, Karnataka, Kerala, Pondicherry, Tamil Nadu

Central Madhya Pradesh, rest of Uttar Pradesh

Eastern Bihar, Chhattisgarh, Eastern Uttar Pradesh, Jharkhand, Orissa, West Bengal

Northeast Arunachal Pradesh, Assam, Manipur, Meghalaya, Mizoram, Nagaland, Sikkim, Tripura 


\section{References}

Allan, N. J. R. (1986). Accessibility and altitudinal zonation models of mountains. Mountain Research and Development, 6, 11-18. http://dx.doi.org/10.2307/3673384

Anderson, J. R. (2003). Risk in rural development: Challenges for mangers and policy makers. Agricultural Systems, 75, 161-197. http://dx.doi.org/ 10.1016/S0308-521X(02)00064-1

Aneani, F., Anchirinah, V. M., Owusu-Ansah, F., \& Asamoah, M. (2011). An analysis of the extent and determinants of crop diversification by cocoa (Theobroma cacao) farmers in Ghana. African Journal of Agricultural Research, 6(18), 4277-4287.

Administrative Staff College of India [ASCI]. (2006). Impact Evaluation Study of Kisan Call Centers. Hyderabad: Author.

Barghouti, S., Kane, S., Sorby, K., \& Ali, M. (2004). Agricultural diversification for poor: Guidelines for practitioners (Agriculture and Rural Development Discussion Paper-I). Washington, D.C.: The World Bank.

Basant, R., \& Kumar, B. L. (1989). Rural nonagricultural activities in India: A review of available evidence. Social Scientist, 17(1-2), 13-17. http://dx.doi.org/10.2307/3520109

Benziger, V. (1996). Small fields, big money: Two successful programs in helping small farmers making transition to high value added crops. World Development, 24(11), 1681-1693. http://dx.doi.org/10.1016/0305-750X(96)00070-8

Bhagat, R. B. (2005). Rural-urban classification and municipal governance in India. Singapore Journal of Tropical Geography, 26, 61-73. http://dx.doi.org/ 10.1111/j.0129-7619.2005.00204.x

Bhattacharyya, R. (2008). Crop diversification: Asearch for an alternative income of the farmers in the state of West Bengal in India. Paper presented at the International Conference on Applied Economics (ICOAE), Kastoria, Greece, May 2008.

Binswanger, H. P., \& McIntire, J. (1987). Behavior and material determinants of production relations in land abundant tropical agriculture. Economic Development and Cultural Change, 36, 73-99. http://dx.doi.org/10.1086/451637

Bugri, J. T. (2008). The dynamics of tenure security, agricultural production and environmental degradation in Africa: Evidence from stakeholders in north-east Ghana. Land Use Policy, 25, 271-285. http://dx.doi.org/10.1016/j.landusepol.2007. $\underline{08.002}$

Chadha, G. K., \& Sahu, P. P. (2002). Post-reforms setbacks in employment: Issues and need for further scrutiny. Economic and Political Weekly, 37(21), 1998-2026.

Chan, Y. H. (2005). Multinomial logistic regression. Biostatistics 305, Singapore Medical Journal, 46(6), 259-269.

Chand, R. (1996). Diversification through high value crops in Western Himalayan Region: Evidence from Himachal Pradesh. Indian Journal of Agricultural Economics, 41(4), 652-663.

Chand, R., Prasanna, P. A. L., \& Singh, A. (2011). Farm size and productivity: Understanding the strengths of smallholders and improving their livelihoods. Economic and Political Weekly (Supplement), 46 (26-27), 5-11.

Chatterjee, S., Saikia, A., Dutta, P., Ghosh, D., Pangging, G., \& Goswami, A. K. (2006). Biodiversity significance of North East India (Background paper for the study on Natural Resources, Water and Environment Nexus for Development and Growth in North Eastern India). New Delhi: WWF-India.

Chitnis, S. (1997). Definition of the terms scheduled castes and scheduled tribes: A crisis of ambivalence. In V. A. P. Panandiker (Ed.), The politics of backwardness: Reservation policy in India. New Delhi: Centre for Policy Research.

Danish International Development Agency [DANIDA]. (2000). Identification Report, Watershed Development Project, Chittagong Hill Tracts (pp. 12-17). Bangladesh: Author.

De, U. K., \& Chattopadhyay, M. (2010). Crop diversification by poor peasants and role of infrastructure: Evidence from West Bengal. Journal of Development and Agricultural Economics, 2(10), 340350.

Department of Agriculture \& Cooperation, Ministry of Agriculture [DAC-MOA]. (2000a). Vision 2020 and strategic action plan for agriculture — Part I and Part II. New Delhi: Ministry of Agriculture, Government of India.

Department of Agriculture \& Cooperation, Ministry of Agriculture [DAC-MOA]. (2000b). National agricultural policy. New Delhi: Ministry of Agriculture, Government of India. 
Dhandapani, K. R., \& Rath, B. (2004). India. In T. Pratap (Ed.), Sustainable Farming Systems in Upland Areas. Tokyo: Asian Productivity Organization.

Dorjee, K., Broca, S., \& Pingali, P. L. (2003).

Diversification in South Asian Agriculture: Trends and Constraints (ESA Working Paper No. 03-15).

Rome: Agricultural and Development Economics Division, Food and Agriculture Organization.

Dyck, J., Huang, S., \& Wailes, E. (1993, 10-13 August). Structural change and competitiveness of the Asian rice economies in Taiwan, Korea and Japan. In Proceedings of the First Asian Conference of Agricultural Economists, Seoul, South Korea.

Ellis, F. (1989). Peasant economics: Farm housebolds and agrarian development. New York: Cambridge University Press.

Faminow, M. D., Klein, K. K., \& Project Operation Unit. (2001). On-farm testing and dissemination of agroforestry among slash-and-burn farmers in Nagaland, India. Development in Practice, 11, 471-485. http://dx.doi.org/10.1080/09614520120066756

Feder, G., Onchan, T., \& Chalamwong, Y. (1988). Land policies and farm performance in Thailand's forest reserve areas. Economic Development and Cultural Change, 36, 483-501. http://dx.doi.org/10.1086/451671

Goswami, N. (2010). India's Northeast 2010: Four alternative futures (IDSA Occasional Paper No. 13). New Delhi: Institute for Defence Studies and Analyses.

Government of Bihar [GoB]. (2010). Report of the Steering Group on Vision of Agriculture Development in Bihar. Department of Agriculture, Government of Bihar.

Government of India [GoI]. (2001). Report of the Working Group on Agricultural Development in Eastern \& Northeastern India for the Formulation of the Tenth Five Year Plan (TFYP Working Group Sr. No. 40/2001). Planning Commission, Government of India.

Government of India [GoI]. (2004). Estimating loss of borticulture produce due to non-availability of post harvest \& food processing facilities in Bihar \& UP. Planning Commission, Government of India. New Delhi: ASET.

Government of India [GoI]. (2008). Eleventh Five Year Plan (2007-2012): Agriculture, rural development, industry, services and physical infrastructure (Volume 3). Planning Commission, Government of India. New Delhi: Oxford University Press.
Government of India [GoI]. (2012). Economic Survey, 2011-12. New Delhi: Ministry of Finance, Government of India.

Gulati, A., \& Ganguly, K. (2008). Beyond grain security: Agriculture tomorrow. India 2008. New Delhi: The Business Standard.

Guvele, C. A. (2001). Gains from crop diversification in the Sudan Gezira scheme. Agricultural Systems, 70, 319-333. http://dx.doi.org/10.1016/S0308$\underline{521 X(01) 00030-0}$

Haque, T., Bhattacharya, M., Sinha, G., Kalra, P., \& Thomas, S. (2010). Constraints and potentials of diversified agricultural development in Eastern India (Project Report). New Delhi: Council for Social Development.

Hosmer, D. W., \& Lemeshow, S. (1989). Applied logistic regression. New York: Wiley\& Sons.

Huang, J., \& Rozelle, S. (1994). Environmental stress yields in China. American Journal of Agricultural Economics, 77(4), 853-864. http://dx.doi.org/10.2307/1243808

Joshi, P. K. (2004). Diversification of agriculture in more competitive environment. In M. Ali (Ed.), Agricultural Diversification and International Competitiveness. Tokyo: Asian Productivity Organization.

Joshi, P. K., Gulati, A., Birthal, P. S., \& Tiwari, L. (2004). Agricultural diversification in South Asia: Pattern, determinants and policy implications. Economic and Political Weekly, 39(24), 2457-2467.

Joshi, P. K., Gulati, A., \& Cummings, Jr. R. (Eds.). (2007). Agricultural diversification and smallholders in South Asia. New Delhi: Academic Foundation.

Joshi, A. P., Srinivas, M. D., \& Bajaj, J. K. (2003). Religious demography of India. Chennai, India: Centre for Policy Studies.

Kapoor, A. (2011). State competitiveness report 2011 in business world. Institute of Competitiveness. http://competitiveness.in

Kar, G., Singh, R., \& Verma, H. N. (2004). Alternative cropping strategies for assured and efficient crop production in upland rainfed rice areas of Eastern India based on rainfall analysis. Agricultural Water Management, 67, 47-62. http://dx.doi.org/10.1016/j.agwat.2003.12.005 
Kar, G., \& Verma, H. N. (2002). Improved sustainability of rainfed upland sub-humid ecosystem of watershed based on probabilistic rainfall. In B. Venkateswara Rao, K. Ram Mohan Reddy, C. Sarala, \& K. Raju, (Eds.), Hydrology and Watershed, vol. 1 (pp. 318-327). Hyderabad, India: BSP Books Pvt. Ltd.

Kasem, S., \& Thapa, G. B. (2011). Crop diversification in Thailand: Status, determinants, and effects on income and use of inputs. Land Use Policy, 28, 618628. http://dx.doi.org/10.1016/j.landusepol. 2010.12.001

Knowler, D., \& Bradshaw, B. (2007). Farmers' adoption of conservation agriculture: Areview and synthesis of recent research. Food Policy, 32, 25-48. http://dx.doi.org/10.1016/j.foodpol.2006.01.003

Knudsen, J. L., \& Khan, N. A. (2002). An exploration ofthe problems and prospects of integrated watershed development in the CHT. In N. A. Khan, M. K. Alam, S. K. Khisa, \& M. Millat-e-Mustafa (Eds.), Farming practices and sustainable development in the Chittagong Hill Tracts (pp. 165-180). Chittagong, Bangladesh: CHTDB and VFFP-IC.

Koppel, B., \& Zurick, D. (1988). Rural transformation and the future of agricultural development policy in Asia. Agricultural Administration and Extension, 28, 283-301. http://dx.doi.org/10.1016/02697475(88)90003-7

Kumar, A. (2009). Rural employment diversification in Eastern India: Trends and determinants. Agricultural Economics Research Review, 22(1), 47-60.

Kumar, A., Kumar, S., Singh, D. K., \& Shivjee (2011). Rural employment diversification in India: Trends, determinants and implications on poverty. Agricultural Economics Research Review, 24, 361-372.

Kumar, P., \& Mathur, V. C. (1996). Structural changes in the demand for food in India. Indian Journal of Agricultural Economics, 51(4), 664-673.

Kumar, P., Mruthyunjaya, \& Birthal, P. S. (2007). Changing consumption pattern in South Asia. In P. K. Joshi, A. Gulati, \& R.Cummings Jr. (Eds.), Agricultural Diversification and Smallholders in South Asia (pp. 151-187). New Delhi: Academic Foundation.

Lianzela. (1997). Effects of shifting cultivation on the environment. With special reference to Mizoram. International Journal of Social Economics, 24, 785-790. http://dx.doi.org/10.1108/03068299710178847
Lipton, M. (1968). The theory of the optimizing peasant. Journal of Development Studies, 4, 327-351. http://dx.doi.org/10.1080/00220386808421262

McNamara, K. T., \& Weiss, C. (2005). Farm household income and on- and off-farm diversification. Journal of Agricultural and Applied Economics, 37(1), 37-48.

Mukhopadhyay, A., \& Rajaraman, I. (2007). Rural unemployment 1999-2005: Who gained, who lost? Economic and Political Weekly, 37(21), 3116-3120.

Nagaland Environmental Protection and Economic Development [NEPED] \& International Institute of Rural Reconstruction [IIRR]. (1999). Building upon traditional agriculture in Nagaland, India. Nagaland, India and, Silang, Cavite, Philippines: Author.

National Academy of Agriculture Sciences [NAAS]. (2001). Strategies for agricultural research in the Northeast(Policy Paper 9).India: National Academy of Agriculture Sciences.

National Bank for Agriculture and Rural Development [NABARD]. (2010). Infrastructure for Agriculture Development. Occasional Paper-53. National Bank for Agriculture and Rural Development, Mumbai.

National Bank for Agriculture and Rural Development [NABARD]. (2011). Annual Report 2010-11. Mumbai: Author

National Sample Survey Organization [NSSO]. (2006). Livestock ownership across operational land holding classes in India, 2002-03(Report No. 493). National Sample Survey Organization, Ministry of Statistics and Programme Implementation, Government of India.

Naylor, R. (1991). The rural labor market in Indonesia. In S. Pearson, W. Falcon, P. Heytens, E. Monke, \& R. Naylor (Eds.), Rice policy in Indonesia (pp. 58-98). Ithaca, New York: Cornell University Press.

Papademetriou, M. K., \& Dent, F. J. (Eds.). (2001). Crop diversification in the Asia-Pacific region. Bangkok: Regional Office for Asia and the Pacific, Food and Agriculture Organization of the United Nations.

Pastakia, A., \& Oza, S. (2011). Livelihood augmentation in rainfed areas: $A$ strategy hand book for the practitioner (VolumeIII, Catching the Virtual Bus: ICT for Augmenting Rural Livelihoods). Ahmedabad, India: Development Support Centre.

Pingali, P. L. (2004, 12-13 February). Agricultural diversification: Opportunities and constraints. FAO Rice Conference. Rome: Food and Agricultural Organization of the United Nations. 
Pingali, P. L. (2006). Westernization of Asian diets and the transformation of food systems: Implications for research and policy. Food Policy, 32, 281-298. http://dx.doi.org/10.1016/j.foodpol.2006.08.001

Pingali, P. L., Khwaja, Y., \& Meijer, M. (2005). Commercializing small farms: Reducing transaction costs(ESA Working Paper No.05-08).Rome: Agriculture and Development Economics Division, Food and Agriculture Organization.

Prasad, B. K. (2004). Population and family life education. New Delhi: Anmol Publications Pvt. Ltd.

Rahman, S. (2009). Whether crop diversification is a desired strategy for agricultural growth in Bangladesh? Food Policy, 34, 340-349. http://dx.doi.org/10.1016/j.foodpol.2009.02.004

Rao, P. P., Birthal, P. S., \& Joshi, P. K. (2006).

Diversification towards high value agriculture: Role of urbanization and infrastructure. Economic and Political Weekly, 41(26), 2747-2753.

Rao, P. P., Birthal, P. S., Joshi, P. K., \& Kar, D. (2004). Agricultural diversification in India and role of urbanization (MTID Discussion Paper No. 77). Washington, D.C.: International Food Policy Research Institute.

Rasul, G., \& Thapa, G. B. (2003). Sustainability analysis of ecological and conventional agricultural systems in Bangladesh. World Development, 31(10), 17211741. http://dx.doi.org/10.1016/S0305750X(03)00137-2

Rasul, G., Thapa, G. B., \& Zoebisch, M. A. (2004). Determinants of land-use changes in the Chittagong Hill Tracts of Bangladesh. Applied Geography, 24, 217-240. http://dx.doi.org/10.1016/j.apgeog.2004.03.004

Reardon, T., Barret, C. B., Kelly, B., \& Savadogo, K. (2001). Sustainable versus unsustainable agricultural intensification in Africa: Focus on policy reforms and market conditions. In R. Lee, \& C. B. Barret (Eds.), Tradeoffs and synergies? Agricultural intensification, economic development and the environment (pp. 365-381). Wallingford, UK: CABI publishing.

Retherford, R. D., \& Choe, M. K. (1993). Statistical models for causal analysis. New York: John Wiley and Sons. http://dx.doi.org/10.1002/9781118033135

Rogers, M. E. (1995). Diffusion of innovations (4th edition). New York: The Free Press.

Ryan, J. G., \& Spencer, D. C. (2001). Future challenges and opportunities for agricultural $\mathrm{R}$ and $\mathrm{D}$ in the semi-arid tropics. Patancheru, India: International Crops Research Institute for the Semi-Arid Tropics. Salasya, B., Mwangi, W., Mwabu, D., \& Diallo, A. (2007). Factors influencing adoption of stresstolerant maize hybrid (WH502) in Western Kenya. African Journal of Agricultural Research, 2(10), 544-551.

Shukla, S. P. (1997). Transforming the Northeast (High Level Commission Report to the Prime Minister). New Delhi: Government of India.

Singh, M. A. (2009). A study on illegal immigration into North-East India: The case of Nagaland (IDSA Occasional Paper No.8). New Delhi: Institute for Defence Studies and Analyses.

Singh, R. B., Kumar, P., \& Woodhead, T. (2002). Smallholder farmers in India: Food security and agricultural policy. Bangkok: FAO Regional Office for Asia and the Pacific.

Singh, S. P., \& Sahoo, B. K. (2007). Diversification of agricultural economy towards horticulture and livestock: Regional variations, convergence and determinants. The Indian Journal of Labour Economics, 50(4), 657-672.

Statacorp. (2007). Stata Statistical Software: Release 10, Statacorp LP, College Station, Texas.

Tangjang, S. (2009). Traditional slash and burn agriculture as a historic land use practice: A case study from the ethnic noctes in Arunachal Pradesh, India. World Journal of Agricultural Sciences, 5(1), 70-73.

Thapa, G. B. (1998). Nepal's experiences in hill agriculture. In E.C. Chapman, B. Bouahom, \& P. K. Hansen (Eds.), Upland farming systems in Lao P.D.R.: Problems and opportunities for livestock, No. 87(pp. 48-53). Proceedings of an international workshop held 18-23 May 1997, Vientiane, Laos. Canberra: Australian Centre for International Research (ACIAR).

Turkelboom, F., Van, K. K., Ongprasert, S., Sutigoolabud, P., \& Pelletier, J. (1996). The changing landscape of the Northern Thai hills: Adaptive strategies to increasing land pressure. Montane Mainland Southeast Asia in transition (pp. 436-461). Thailand: Chiang Mai University.

Van den Berg, M. M., Hengsdijk, H., Wolf, J., Ittersum, M. K. V., Guanghuo, W., \& Roetter, P. (2007). The impact of increasing farm size and mechanization on rural income and rice production in Zhejiang province, China. Agricultural Systems, 94, 841-850. http://dx.doi.org/10.1016/j.agsy.2006.11.010 
Visaria, P. (1995) Rural non-farm employment in India: Trends and issues for research. Indian Journal of Agricultural Economics, 50(3), 398-409.

von Braun, J. (1995). Agricultural commercialization: Impacts on income and nutrition and implications for policy. Food Policy, 20(3), 187-202. http://dx.doi.org/10.1016/0306-9192(95)00013-5

Walworth, J. L. (2009). Soil Fertility Basics- Crop Production and Soil Management Series. Cooperative Extension Service Publication FGV00242A, University of Alaska Fairbanks.
Warner, R. M. (2008). Applied statistics: From bivariate through multivariate techniques. Thousand Oaks, California: Sage Publications.

World Bank. (2007). World Development Report 2008 : Agriculture for Development. Washington D.C.: Author. Retrieved from http://web.worldbank.org/ WBSITE/EXTERNAL/EXTDEC/EXTRE SEARCH/EXTWDRS/0, ,contentMDK:23062293 $\sim$ pagePK:478093 piPK:477627 theSitePK: 477624,00.html 